\title{
6-オキシメチルルマジンとそのリン酸エステルの合成
}

（胎和 41 年 3 月 15 日受理）

杉 浦 桂・藤 幹 保*1

\section{1 緒富}

Crithidia fasciculata の生長促進物買が ホウレン草に存在する という報告がある122。またホウレン草のプテリンよう物質が光り ン酸化の補助因子として役立つことも知られている3。 しかしこ れらの化学的性質はまったく不明である。これらの化合物を追求 する過程で新しいプテリジン誘導体 6ーオキシメチルルマジン(I) を取りだしたせ。これを類似した構造を有する 6-オキシメチルプ テリン*2は，そのリン酸エステルののジヒドロ体が菜酸生合成の中 間体であることが知られているい6)。の新しい物質の生化学的意 義を倹討するため，6-オキシメチルルマジンとそのリン酸エステ ルを合成した。ここにそれらの合成方法を報告する。<smiles></smiles>

(I) $\mathbf{R}=\mathbf{H}$

(II) $\mathrm{R}=\mathrm{PO}_{3} \mathrm{H}_{2}$

(II) $\mathrm{R}=\mathrm{P}_{2} \mathrm{O}_{6} \mathrm{H}_{3}$

\section{2 実}

\subsection{6-オキシメチルルマジン(I)の合成}

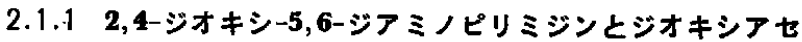

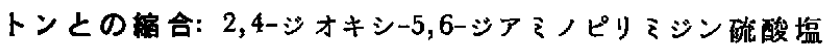
$(0.90 \mathrm{~g} / 20 \mathrm{ml}$, 水) と塩化バリウム $(1.0 \mathrm{~g} / 5.0 \mathrm{ml}$, 水 $)$ とをまぜ, 湯 浴中で 10 分間加熱し, 冷却して硫酸バリウムをロ過し, $5 \mathrm{ml}$ の水 で洗浄する。口液に L-システイン塩酸塭》 $(0.87 \mathrm{~g})$ とジオキシ アセトン $(0.90 \mathrm{~g})$ を含む $4 \mathrm{~mol} / l$ 酢酸ナトリウム溶液 $30 \mathrm{ml}$ を 加え 24 時間かきまぜる。反応生成物を $\boldsymbol{n}$ ーブタノール：メタノー ル: 水(2:1:1 体積)を展開戍として, セルロースカラム $(7.0 \times$ $24.0 \mathrm{~cm}$ ) で分崩する(合計 3 本)。このとき,副生成物として生じた メチルルマジンタ が分剀される。すなわちまずメチルルマジンが,

*1 Katsura SugivRA, Miki GoTo 学留院大学理学部化学 教室, 東京都費盘区目白

*22-アミノ-4-オキシブテリシンをブテリンと称す.

1) A. Wacker, E. R. Lochmann, Z. Naturforsch., 14b, 222(1959).

2) I. Ziegler, "Ergebnisse der Physiologie, Biologischen Chemie und Experimentellen Pharmakologie", ed. by K. Kramer, O. Krayer, E. Lehnartz, A. V. Muralt, H. H. Weber, Springer-Verlag, Berlin(1965) Vol. 56, p. 28.

3) F. I. Maclean, Y. Fujita, H. S. Forrest, J. Myers, Science, 149, 636(1965).

4) K. Sugiura, M. Goto, J. Biochem., "Isolation and Identification of 6-Hydroxymethyllumazine from Spinach"[投稿忡].

5) T. Shiota, M. N. Disraely, Biochim. Biophys. Acta, 52, 467(1961).

6) L. Jaenicke, Chan, Ph. C, Angew. Chem., 72, 752(1960).

7) C. M. Baugh, E. Shaw, J. Org. Chem., 29, 3610(1964).

8) R. B. Angier, J. H. Boothe, J. H. Mowat, C. W. Waller, J. Semb, J. Am. Chem. Soc., 74, 408(1952).
つづいて目的物オキシメチルルマジンが流出する。後者を $40^{\circ} \mathrm{C}$ 以下で濃縮乾固する。残留物の一部を，5\% 水酸化ナトリゥム楁 液に溶解し，微粉末の二酸化マンガンを少量加え，湯浴中で 10 分間加熱すると，ルマシン-6-カルボン酸8)のほかに少量のルマ ジンー7ーカルボン酸故が生成する(ペーパークロマト，紫外吸取に より確認)。そこで，6-異性体と 7-異性体との分離の目的て，上 記の乾固物を少量の $5 \%$ アンモ二ア水に溶解し, Dowex $1 \times 8$ (ギ 酸形)カラム $(6.0 \times 20.0 \mathrm{~cm})$ に吸着させる。展開敖はアンモニアー ギ酸の綏衝溶液(ギ酸濃度 $0.045 \mathrm{~mol} / l$ ) で pH 9.0 から pH 7.6 にわたり展開する。

まず 6-異性体が，つぎに近接して 7-異性体が流出する。6-異 性体の溶出液 $6.0 l$ を $10 \%$ アンモニア水で pH 9.0 にしたの ち, Dowex $1 \times 8$ (キ酸形) カラム $(3.0 \times 13.0 \mathrm{~cm})$ に再吸着し, 力 ラムを水 $(2.0 l)$ でよく洗浄したのち，ギ酸 $\left(2 \times 10^{-4} \mathrm{~mol} / l\right) て ゙$ 溶牢する(全溶出液 $200 \mathrm{ml}$ )。溶出液を $10 \%$ アンモニア水で $p H$

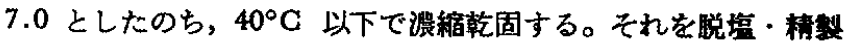
の目的でセルロースカラム $(7.5 \times 23.0 \mathrm{~cm})$ でイソプロパノール: $1 \%$ アンモニア水(2:1 体積)を展開威として 展開する。この操 作を 2 回くり返す。溶出液を $40^{\circ} \mathrm{G}$ 以下で浱縮し少量の水に浴解 し，No. 4 グラスフィルターでロ過，ふたたび乾固したのち, 95 \%エタノールで再結晶する。

淡黄褐色針状結晶 $17.5 \mathrm{mg}$ を得る $\left(232^{\circ} \mathrm{C}\right.$ でシンター状とな

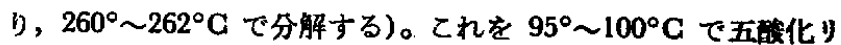
ン存在下で真空乾燥する。

分析值 C $43.48 \%$, H $3.76 \%, \mathrm{~N} 28.32 \%$

$\mathrm{G}_{7} \mathrm{H}_{6} \mathrm{O}_{3} \mathrm{~N}_{4}$ (I) としての

計算值 C $43.00 \% ，$ H $3.12 \% ， \mathrm{~N} 28.86 \%$

UV 吸収: $0.1 \mathrm{~N}$ 水酸化ナトリウム中での $\lambda_{\max } 256 \mathrm{~m} \mu(\varepsilon 18.9$ $\left.\times 10^{3}\right), \quad 372 \mathrm{~m} \mu\left(6.38 \times 10^{3}\right), \quad \lambda_{\mathrm{min}} 229 \mathrm{~m} \mu\left(\varepsilon 9.05 \times 10^{3}\right), 300$ $\left(1.59 \times 10^{3}\right) 。 0.1 \mathrm{~N}$ 塭酸中での. $\lambda_{\max } 231 \mathrm{~m} \mu\left(\epsilon 13.5 \times 10^{3}\right), 390$ $\mathrm{m} \mu\left(8.08 \times 10^{3}\right), \lambda_{\mathrm{min}} 218 \mathrm{~m} \mu\left(\varepsilon 11.5 \times 10^{3}\right), 274 \mathrm{~m} \mu\left(1.18 \times 10^{\circ}\right) 。$ ペーパークロマト $R_{f}$ 值: A $0.62(0.62), B 0.34(0.34), C$ $0.56(0.56)$, D 0.19(0.19); 展開, A; $3 \%$ 场化アンモン,

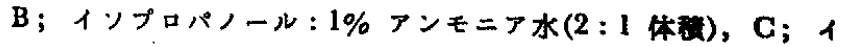

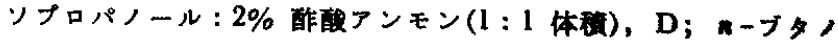

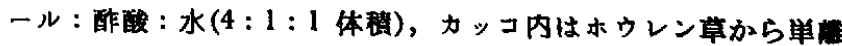
したプテリシンの $\boldsymbol{R}_{f}$ 值を示す。

生成物（I）は，ホウレン草から得られたブテリジンに一致する (UV 吸収,ペーパークロマト的に同定)。

\section{1 .2 2-オキシ-4-アミノ-6-オキシメテルプテリジンからの} 合成: Baugh, Shaw? の方法で合成した 2-オキシ-4-アミノ-6オキシメチルプテリシン*3の粗生成物 $900 \mathrm{mg}$ を $0.1 \mathrm{~N}$ 水酸化

*3 Baugh, Shaw は,この方法さ，目的物が単一に得られ ろことを報告しているが，著者らの追赫では、反店生成 物は，2-オキシー4-アミノ-6(7)-オキシメチルプテり ン, 2-オキシ-4-アミノ-6(7)-メチルブテリシンの混合 物であった。 
ナトリウ $(13 \mathrm{~m} l)$ に溶解し，湯浴中で 1 時間加熱する。それを 2.1 .1 と同じ方法で分離精製するとI が $80 \mathrm{mg}$ 得られる。

2.2 ルマジン-6-メチルホスフェイト(II)とピロホスフェイト (III)の合成

2.2.1 リン酸化: $40 \mathrm{mg}$ のと $4.0 \mathrm{~g}$ のピロリン酸を封管中 (暗所)で， $65^{\circ} \mathrm{G}$ で加熱しながらかきまぜる(18 時間)。その後反 応液を $5^{\circ} \mathrm{G}$ 以下にたもちながら水 $(30 \mathrm{ml})$ を加える。これに 600 mg の Norite A を加えケイ光物質を吸着させ，活性炭を冷水で 洗浄する。そののち，エタノール：6\% アンモ二ア水(1:1体積) $(40 \mathrm{ml})$ で, 冷時溶離する。溶離液を $30^{\circ} \mathrm{C}$ 以下で浱縮乾固する。

2.2.2 クロマトクラフィー：得られた残留物を少量の水に溶 加し, Dowex 1X8(Cl 形) (200〜400メッシュ)カラム $(2.5 \times 22.0$ $\mathrm{cm})$ に吸着し，混合槽に水 $(3.0 l)$ ，上段槽に $0.2 \mathrm{~N}$ 塭酸 $-0.2 \mathrm{~N}$ 食 塩水溶液を使用してのグレディエント法りで展開する。展開平均 流速は, $1.6 \mathrm{ml} / \mathrm{min}$ で $10 \mathrm{ml}$ ずつのフラクションにわけとる。 因 1 に示寸流出状態は，各フラクションの $0.25 \mathrm{ml}$ をとり，それ

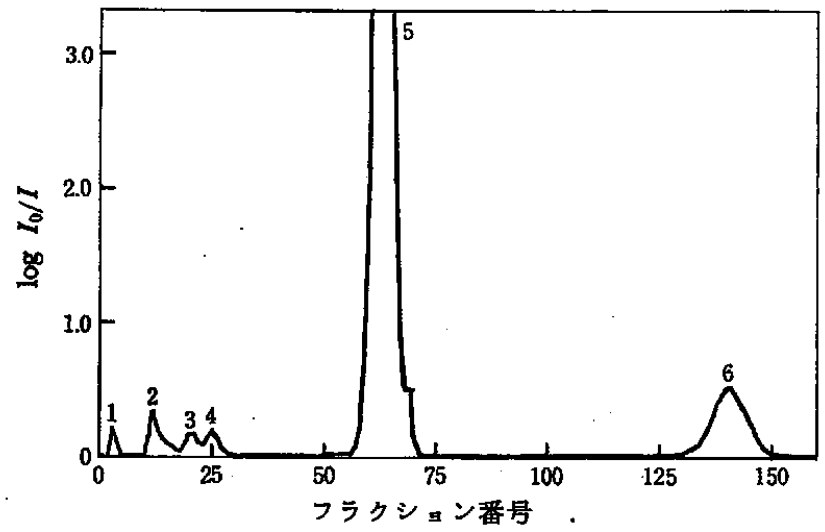

図 1 Dowex $1 \times 8(\mathrm{Cl}$ 形)カラムによるリン酸エステルの分離

に $0.2 \mathrm{~N}$ 水酸化ナトリウム $3.0 \mathrm{ml}$ を混合し, $256 \mathrm{~m} \mu$ の吸収を 測定して得た。図のピークをはじめから，1，2，3，4，5，6 する。ピーク番号 1，4 注不明な物资であり，2 6-メチルルマ ジン，3は 6-オキシメチルルマシンであることをぺーパークロ マト，紫外吸収により同定した。ピーク番号 5(フラクション番 号 57〜70)の溶出液を $4 \mathrm{~N}$ 水酸化カリウムで $p \mathrm{H} 6.5$ にし， 1 $\mathrm{mol} / l$ 酢䁏バリウム $20 \mathrm{ml}$ とエタノール $350 \mathrm{~m} l$ 崖加え, 4 㭙 間冷藏庫に放置する。淡黄色のバリウム塩が得られる。これを 遠心分離し， 80\% エタノールで洗浄する $(90 \mathrm{mg}) 。$ Dowex 50

9) H. Busch, R. B. Hurlbert, V. R. Potter, J. Biol. Chem., 196, 717(1952).
$\left(\mathrm{H}^{+}\right.$形) $(200 \sim 400$ メッシュ) カラム $(2.0 \times 3.0 \mathrm{~cm})$ に少量の水に サスペンドしたバリウム塩を投入し，表面をかきまぜ沈殿を澉か 乙，水で展開する $(50 \mathrm{ml})$ 。溶出液を涷結乾嬠する。残留物を少 墨の水に溶解し，No. 3 グラスフィルターで口䧟し，ふたたび谏 結乾燥する。さらに $0.01 \mathrm{~N}$ 盐酸 $(0.5 \mathrm{ml})$ に溶解し, $0.1 \mathrm{~N}$ 水酸 化ナトリウムで $p \mathrm{H} 7.5$ にする。こ机に3 倍量のエ夕ノールを加 え，3時間冷所に放置したのち幥心分崔する。沈殿を少量の $50 \%$ エタノール・エタノール・エーテルで洗浄する。1 の淡黄色針状 結晶 $12.55 \mathrm{mg}$ を得る $\left(\mathrm{mp}>310^{\circ} \mathrm{C}\right)$ 。 $70^{\circ} \sim 80^{\circ} \mathrm{C}$ で五酸化りン の存在下で真空乾燥する。

分析值 $\mathrm{N} 15.58 \%, \mathrm{P} 7.70 \%$

$\mathrm{C}_{7} \mathrm{H}_{5} \mathrm{~N}_{6} \mathrm{O}_{4} \mathrm{PNa}_{2} \cdot 3 \mathrm{H}_{2} \mathrm{O}$ (II) としての

計算值 $\mathrm{N} 15.10 \% ， \mathrm{P} 8.07 \%$

UV 吸收: $0.1 \mathrm{~N}$ 水酸化ナトyウム中での $\lambda_{\max } 257 \mathrm{~m} \mu(\varepsilon$ $\left.16.35 \times 10^{3}\right), 374 \mathrm{~m} \mu\left(4.80 \times 10^{2}\right), \lambda_{\min } 230 \mathrm{~m} \mu\left(\varepsilon 8.78 \times 10^{3}\right)$, $300 \mathrm{~m} \mu\left(1.20 \times 10^{3}\right)$ 。 $0.1 \mathrm{~N}$ 埴酸中での $\lambda_{\max } 232 \mathrm{~m} \mu(\varepsilon 12.5 \times$ $\left.10^{3}\right), 332 \mathrm{~m} \mu\left(7.30 \times 10^{3}\right), \lambda_{\min } 218 \mathrm{~m} \mu\left(\varepsilon 10.1 \times 10^{3}\right), 274 \mathrm{~m} \mu$ $\left(1.18 \times 10^{3}\right)$ 。

ペーパークロマト $R_{f}$ 值: A 0.82, B 0.08, G $0.33, \mathrm{D} 0.02$ (展開凨は 2.1.1のときと同し符号で示した)。

I は， $p \mathrm{H} 4.5(0.05 \mathrm{~mol} / \mathrm{l}$ 酢酸ナトリウム緩衝溶液 $) ， 26.6$ $\mathrm{V} / \mathrm{cm}$ ，I時間で陽極に $3.0 \mathrm{~cm}$ 移動する。同じ条件でルマジンー 6ーカルボン酸は $3.3 \mathrm{~cm}$ である。

Ilを $2 \mathrm{~N}$ 塩酸中で湯浴で 1 時間加熱すると一部のものが, 6-メ チルルマジン，6-オキシメチルルマシンに加水分解さ机る。同じ 条件で $2 \mathrm{~N}$ 水酸化ナトリゥム中では一部のものが，6-オキシメチ ルルマシンとなる。アルカリホスファターゼ (Sigma Chemical Co., U. S. A. 製品)により, 完全に 6-オキシメチルルマシンに 加水分解される。

ピーク番号 6, フラクション番号 131〜150 をモノホスフェイ トと同様にして，正のナトリウム塭 $0.5 \mathrm{mg}$ 糞色粉末として得 た。この物質は $0.1 \mathrm{~N}$ 掹酸，または $0.1 \mathrm{~N}$ 水酸化ナトりウムと 湯浴中で 1 時間加熱すると，一部が 6-オキシメチルルマシンと モノホスフェイトに扣水分解されるが，アルカリホスフォターゼ によっては加水分解されないので，ルマジンー6-メチルピロホス フェイト(II) と考えられる。

ペーパークロマト $R_{f}$ 值: A 0.88, B $0.04, \mathrm{C} 0.31, \mathrm{D} 0.0$ （屡䦎は2.1.1 のときと同じ符号で示した）.

I $の$ 電気泳動は, pH $4.5(0.05 \mathrm{~mol} / 6$ 酰酸ナト!ウム䌅衝溶 液), $26.6 \mathrm{~V} / \mathrm{cm}, 1$ 時間で陽極に $4.5 \mathrm{~cm}$ 移動する(ルマシシンー 6 -カルポン酸は $3.3 \mathrm{~cm})$ 。 